\title{
THE USE OF RADIOIODINATED ALBUMIN IN METABOLIC STUDIES. THE EFFECTS OF THE LEVEL OF DIETARY PROTEIN AND L-TRIIODOTHYRONINE ON THE CATABOLISM OF RADIOIODINATED HUMAN SERUM ALBUMIN ${ }^{1}$
}

\author{
By FRANK L. IBER,² KURT NASSAU, ${ }^{3}$ IRVIN C. PLOUGH, 4 FLORENCE M. \\ BERGER, WILLIAM H. MERONEY,5 AND KENNETH \\ FREMONT-SMITH 6 \\ (From the Department of Metabolism, Walter Reed Army Institute of Research, \\ Washington, D. C.)
}

(Submitted for publication May 3, 1957; accepted June 26, 1958)

Radioiodinated proteins have been widely used as a convenient tag for plasma proteins since the description by Sterling (1). Recently evidence has been summarized suggesting that in many studies iodinated proteins do not behave as does the native protein (2). The chemical mixture for attaching the iodine label, the number of iodine molecules per protein molecule and the irradiation arising from the label may affect the protein molecule. Thus, proteins iodinated in most laboratories disappear from the plasma more rapidly than protein containing endogenous labels of $\mathrm{N}, \mathrm{C}$ or $S(3-6)$. This difference is decreased by the use of carefully prepared iodinated proteins $(7,8)$ and is probably accounted for on the one hand by denaturation of the iodinated protein (7-9) and on the other hand by slight reutilization of the $\mathrm{N}, \mathrm{C}$ or $\mathrm{S}$ label $(3,4,6)$.

This paper presents a modified method of using human iodinated serum albumin (HISA), commercially prepared, in which the same preparation is employed in both a control and an experimental period. It will be shown that high levels of dietary protein and the administration of large doses of L-triiodothyronine increase the catabolic rate of HISA.

1 An abstract of this article appeared in J. clin. Invest. 1956, 35, 705 .

2 Present address: Postgraduate Medical School, Ducane Rd., London, England.

3 Present address: Chemistry Department, University of Pittsburgh, Pittsburgh, $\mathrm{Pa}$.

4 Present address: Medical Nutrition Laboratory, Fitzsimmons General Hospital, Denver, Colo.

5 Present address: United States Army Tropical Research Medical Laboratory, Puerto Rico.

- Present address: Mary Imogene Bassett Hospital, Cooperstown, N. Y.

\section{METHODS}

Subjects, diets, and collections. All subjects were confined to a metabolic ward throughout the period of study. Liquid diets as previously described (10) were administered in divided feedings. Table I gives pertinent clinical data on the subjects and lists the calculated protein, fat, carbohydrate and caloric content of the diets during each study. An equilibration period of at least three days on the diet was employed before collections were begun. All subjects (except No. 7) received 0.2 ml. Lugol's solution three times daily while under study. Urine and feces were stored under refrigeration throughout the collection period. Collection periods were of 24 hours duration for urine and of 72 or 96 hours duration for feces. Urinary creatinine. was determined on all urine specimens as a check on the completeness of collection. The methods of chemical analysis are those previously described (11).

Labeling of the patient, analysis for radioactivity. HISA was administered intravenously within two days of receipt of the shipment from the manufacturer. ${ }^{7}$ All lots of HISA were dialyzed to determine the fraction of the radioactivity unbound to protein. All lots employed in these studies had less than 3 per cent dialyzable radioactivity. Approximately $100 \mu \mathrm{c}$. was employed for each study of 16 days duration; the dose was doubled for each 8 additional days planned but did not excede $400 \mu \mathrm{c}$. The calculated dose was taken up in a tared tuberculin syringe which was then reweighed. The HISA was given intravenously and the syringe was rinsed three times with the patient's blood while still in place, giving the rinsed blood back to the patient. A standard HISA solution was simultaneously prepared by rinsing the contents of a similar syringe into a volumetric flask employing three rinses with water rather than blood. A Tracer Laboratories well scintillation counter Model DS3 with a Nuclear number 183 scaler was used for counting. Counting periods were in general three minutes but were prolonged when necessary to measure a minimum of 1,000 counts above background.

\footnotetext{
7 Abbott Laboratories radioiodinated serum albumin (RISA®) was used throughout these studies.
} 
TABLE I

Pertinent clinical data and dietary intake on each experimental subject

\begin{tabular}{|c|c|c|c|c|c|c|c|c|c|}
\hline No. & Age & Sex & Diagnosis & Study & Wt. & Protein & CHO & Fat & $\begin{array}{c}\text { Calories/ } \\
\text { day }\end{array}$ \\
\hline 1 & $\begin{array}{l}y r s . \\
20\end{array}$ & $\mathbf{M}$ & $\begin{array}{l}\text { Herniated nucleus pulposis (HNP), } \\
6 \text { weeks postoperative }\end{array}$ & $\begin{array}{l}\text { High protein } \\
\text { Low protein }\end{array}$ & $\begin{array}{r}K g . \\
97\end{array}$ & $\begin{array}{c}\text { Gm./day } \\
292 \\
50\end{array}$ & $\begin{array}{l}\text { Gm./day } \\
279 \\
402\end{array}$ & $\begin{array}{c}\text { Gm./day } \\
125 \\
179\end{array}$ & $\begin{array}{l}3,420 \\
3,390\end{array}$ \\
\hline 2 & 20 & $\mathbf{M}$ & Contracting scars on hand & $\begin{array}{l}\text { High protein } \\
\text { Low protein }\end{array}$ & 87 & $\begin{array}{r}265 \\
44\end{array}$ & $\begin{array}{l}253 \\
269\end{array}$ & $\begin{array}{l}113 \\
204\end{array}$ & $\begin{array}{l}3,100 \\
3,040\end{array}$ \\
\hline 3 & 60 & $\mathbf{M}$ & Senile osteoporosis & $\begin{array}{l}\text { High protein } \\
\text { Low protein } \\
\text { Triiodothy- } \\
\text { ronine } \\
\quad(\mathrm{T}-3)\end{array}$ & 48 & $\begin{array}{r}149 \\
26 \\
149\end{array}$ & $\begin{array}{l}195 \\
207 \\
195\end{array}$ & $\begin{array}{l}42 \\
92 \\
42\end{array}$ & $\begin{array}{l}1,760 \\
1,740 \\
1,760\end{array}$ \\
\hline 4 & 25 & $\mathbf{M}$ & $\begin{array}{l}\text { Adrenalectomized for Cushing's dis- } \\
\text { ease; maintained } 50 \mathrm{mg} \text {. hydrocor- } \\
\text { tisone; } 6 \text { months postoperative }\end{array}$ & $\begin{array}{l}\text { High protein } \\
\text { Low protein } \\
\text { T-3 }\end{array}$ & 72 & $\begin{array}{r}219 \\
41 \\
62\end{array}$ & $\begin{array}{r}236 \\
352 \\
66\end{array}$ & $\begin{array}{r}81 \\
112 \\
22\end{array}$ & $\begin{array}{r}2,540 \\
2,560 \\
710\end{array}$ \\
\hline 5 & 26 & $\mathbf{M}$ & HNP, 8 weeks postoperative & $\begin{array}{l}\text { High protein } \\
\text { Low protein } \\
\text { T-3 }\end{array}$ & 89 & $\begin{array}{r}265 \\
46 \\
46\end{array}$ & $\begin{array}{l}255 \\
380 \\
380\end{array}$ & $\begin{array}{l}111 \\
168 \\
168\end{array}$ & $\begin{array}{l}3,070 \\
3,190 \\
3,190\end{array}$ \\
\hline 6 & 27 & $\mathbf{M}$ & $\begin{array}{l}\text { Obesity and eosinophilic granuloma } \\
\text { of lung and bone irradiated } 5 \text { months } \\
\text { previously }\end{array}$ & $\mathrm{T}-3$ & 100 & 82 & 60 & 7 & 620 \\
\hline 7 & 22 & $\mathbf{M}$ & $\begin{array}{l}\text { Total thyroidectomy for papillary } \\
\text { carcinoma, } 4 \text { months postoperative, } \\
\text { maintained on } 3 \text { grains thyroid per } \\
\text { day }\end{array}$ & $\begin{array}{l}\text { Lugol's } \\
\text { solution }\end{array}$ & 102 & 102 & 502 & 181 & 4,020 \\
\hline
\end{tabular}

Blood samples were drawn 20 minutes after the labeling dose was given and each morning thereafter, using dry heparin as the anticoagulant. Duplicate $1 \mathrm{ml}$. samples of plasma were pipetted into counting tubes and held for counting. Duplicate $1 \mathrm{ml}$. samples of urine were taken from each 24 hour urine collection; two successive 24 hour collections were then combined and aliquots taken for creatinine and nitrogen analysis. When the radioactivity of the urine specimen was too low for accurate counting, concentration of radioactivity was carried out as follows: $10 \mathrm{ml}$. of urine was placed directly in a counting tube and $0.2 \mathrm{ml}$. of $0.1 \mathrm{~N}$ sodium thiosulfate, 1 $\mathrm{ml}$. of 10 per cent nitric acid and $2 \mathrm{ml}$. of 10 per cent silver nitrate were added. The tubes were heated in a boiling water bath for 15 minutes and after cooling were centrifuged to concentrate the precipitated $\mathrm{AgI} \mathrm{I}^{12}$ in the bottom of the tube where it could be counted without removing the supernatant. Pure solutions of $\mathrm{NaI}^{121}$ were totally recovered by this procedure and in urine at least 97 per cent of the radioactivity was recovered (average of 10 urines, 98.8 per cent).

Presentation and interpretation of data. The experimental data are presented as outlined by Berson, Yalow, Schreiber and Post (8). The radioactivity of the plasma samples was plotted as a function of time on semilog. paper; this will be referred to as the "plasma curve." The radioactivity in the urine was also plotted as a function of time on semilog. paper, but it was soon discovered that failure to empty the urinary bladder completely at the end of each collection period introduced considerable fluctuation in many of the urinary curves. For this reason, the urinary excretion data are presented in the per cent remaining curve, a semilog. plot of the radioactivity that remains within the body at any given time plotted as a function of time. Day by day fluctuations are minimal in the per cent remaining curve, rendering it much more susceptible to statistical calculations.

The plasma curve is influenced by one or more of the following: a) changes in plasma albumin concentration or total albumin mass, $b$ ) the disappearance of intact HISA or its labeled breakdown products from the plasma, $c$ ) the synthesis of new albumin, and $d$ ) the catabolism of HISA. If $a$ ) does not change (apart from new synthesis) and the labeled breakdown products of HISA disappear promptly from the plasma, the plasma curve is then a measure of the rate of synthesis and the rate of catabolism of albumin. Similarly, the per cent remaining curve is influenced by $a$ ) the excretion of HISA or of its labeled breakdown products (other than $\mathrm{I}^{121}$ ), $b$ ). the excretion of $\mathrm{I}^{181}$ and $c$ ) the catabolism of HISA. If the only significant product of HISA is labeled iodide and the $\mathrm{I}^{121}$ is excreted promptly, the per cent remaining curve is then a measure of the catabolic rate of albumin. The validity of these assumptions has been considered by Berson and co-workers (8).

None of the present patients had proteinuria. Occasional T-1824 spaces in each patient and daily measure of the serum protein showed no significant change dur- 


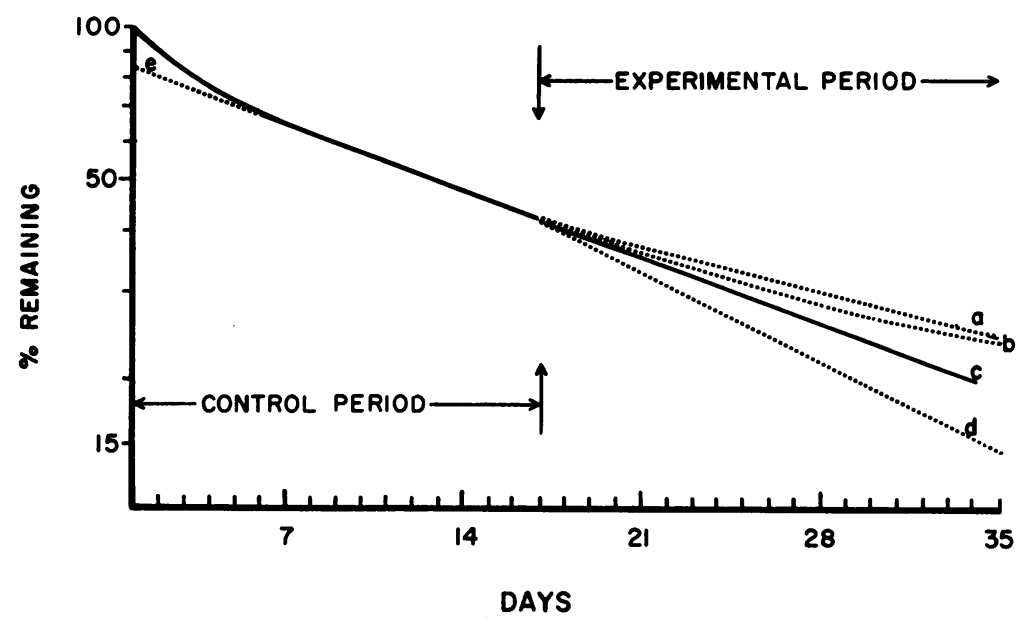

Fig. 1. Hypothetical Per Cent Remaining Curve Showing the Alignment of a Control Period and an Experimental Period

Lines $a, b$ and $d$ represent possible variations from line $c$ obtained by extrapolation of the linear portion of the control period.

ing the studies. In the calculation of the per cent remaining curve, correction was made each day for the $\mathrm{I}^{131}$ removed in the blood sample. When the per cent remaining is 20 per cent or less, this curve becomes exquisitely sensitive to both slight losses of urine and errors in the dose given; for this reason, these factors were carefully controlled.

In the present experiments sufficient HISA was given so that a single label would extend throughout two periods, a control and an experimental one. Figure 1 presents a hypothetical curve to illustrate experimental design. Curve $c$ represents an extension of the best line observed during the control period. It has been demonstrated (8) that such curves tend to become more and more flattened as observation is prolonged, as illustrated in Figure 1, Curve b-they never become steeper. If a variable were introduced at the end of the control period, resulting in a decreased slope (Curve a) the change could not be distinguished from that frequently observed spontaneously. If, however, the control and experimental periods were so aligned that an increased slope occurred during the experimental period (Curve d), the significance of the change would be indisputable. In this event, the magnitude of the change may be estimated by subtracting the per cent change per day ${ }^{8}$ of the control curve (c) from that of the experimental curve (d) and multiplying this difference by the total exchangeable albumin (8) in grams. This yields a minimal estimate of the increased breakdown of albumin in grams per day, for the extrapolated control curve, had it remained undisturbed, might have gradually flattened (Curve $b$ ).

8 The half-life $\left(t_{1 / 2}\right)$ is the time necessary for the plasma radioactivity curve (or the per cent remaining curve) to reach $1 / 2$ of its initial value and is obtained graphically. The per cent change per day is calculated from the formula, $\ln 2 / t_{1 / 2} \times 100$.
The statistical calculation in each instance is to compare the slope of the line on the left half of the graph with the slope of the line on the right half of the graph (12). In these calculations, as employed later, the first six points on the graph are arbitrarily omitted from consideration since this number of points seems to include the necessary time for the equilibration of the HISA with the extravascular albumin pool. Unless qualified, "significant" means significant at the 1 per cent level.

Influence of protein content of the diet-Experimental and results. Five subjects were studied (Table I, Subjects 1 through 5). Two isocaloric diets were employed in the study of each subject, one containing 0.5 gram and the other 3.0 grams of protein per $\mathrm{Kg}$. of body weight. A representative study is illustrated in Figure 2. After the subject had equilibrated to the low protein diet (not shown in Figure 2), he was given HISA and the plasma levels and urinary excretion of radioactivity were measured for two weeks. The diet was then abruptly changed on Day 15 to high protein content and the radioactivity measurements were continued long enough to detect any change in the slope of the curves (Days 15 to 21). A second dose of HISA 9 was then given (Day 21) while the subject remained on the high protein diet. After the new curves were established (Days 21 to 35) the diet was abruptly returned to the low protein (Day 36). The first per cent remaining curve in Figure 2 shows more rapid catabolism of HISA when the protein intake is

\footnotetext{
${ }^{9}$ If appreciable plasma radioactivity were left from the previous dose of HISA, the size of the second dose was increased to the maximum permissible to lessen the influence of a different lot of HISA. The "total dose" employed in the calculation of the per cent remaining was the amount given plus the amount still present in the body. The latter was estimated from the plasma activity and the measured pool size.
} 
suddently shifted from low to high. Similarly, the second per cent remaining curve in Figure 2 shows a flattening when the dietary protein intake is suddenly dropped from high to low; unlike the first curve, however, this does not necessarily indicate a change in albumin metabolism since the same change in the curve might have been seen without any change in the experimental situation (see Figure 1 and the discussion of Figure 1).

The dietary protocols for three of the five subjects were identical to that illustrated in Figure 2; in the other two subjects, the sequence was reversed, the diets being high protein, low protein and high protein in that order. The composite experience of all five subjects is shown in Figures 3 and 4 . In four of the five studies there was significantly increased catabolism of HISA when the dietary protein was suddenly increased (Figure 3 ). Although three of the five studies showed a statistically significant decrease in slope of the per cent remaining curve when protein intake was suddenly decreased
(Figure 4), the normal flattening of HISA curves (see Figure 1) does not permit interpretations of changes in this direction. The scatter observed in the plasma values was so great that the changes were not interpretable (sample data, Figure 2).

Discussion. Steinbock and Tarver, in studies using $\mathrm{S}^{35}$ labeled amino acids in rats, found that the half-life of total serum protein was 17 days in animals eating a protein free diet, 5.1 days in animals on a diet containing 25 per cent protein and 2.9 days in animals on a diet containing 65 per cent protein (13). Liver tissue removed from animals maintained on a high protein diet incorporated amino acids more rapidly than liver from animals on a low protein diet (14). Blahd, Fields and Goldman (15) measured the effect of diet on albumin turnover in patients with the nephrotic syndrome and found that an increased level of dietary protein accelerated the albumin synthesis.

The present study shows that the catabolism of HISA

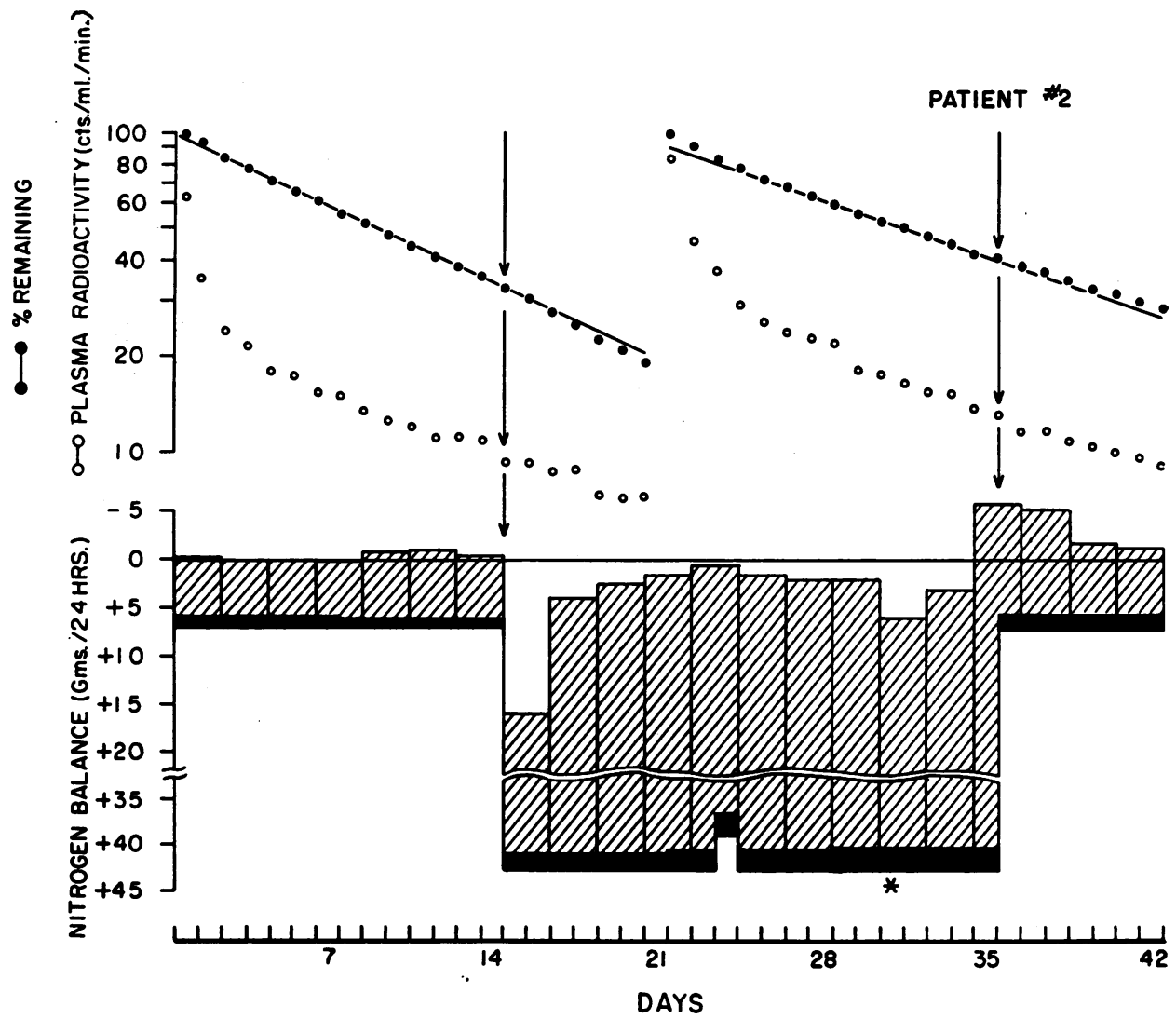

Fig. 2. Effect of Varying Protein Intake on Albumin Turnover

The diet was changed from $0.5 \mathrm{Gm}$. protein to $3 \mathrm{Gm}$. protein per $\mathrm{Kg}$. body weight. The straight lines in the per cent remaining curves are extrapolated from the early portion (Days 1 through 14) and (Days 21 through 35) into the later portion. From Days 14 through 21 the experimental points drop below the line indicating increased catabolism. Plasma radioactivity has been divided by $10^{4}$. Asterisk indicates patient had one meal of solid food-part of usual diet removed to keep intake constant. The scale for the plasma values is arbitrarily chosen. 


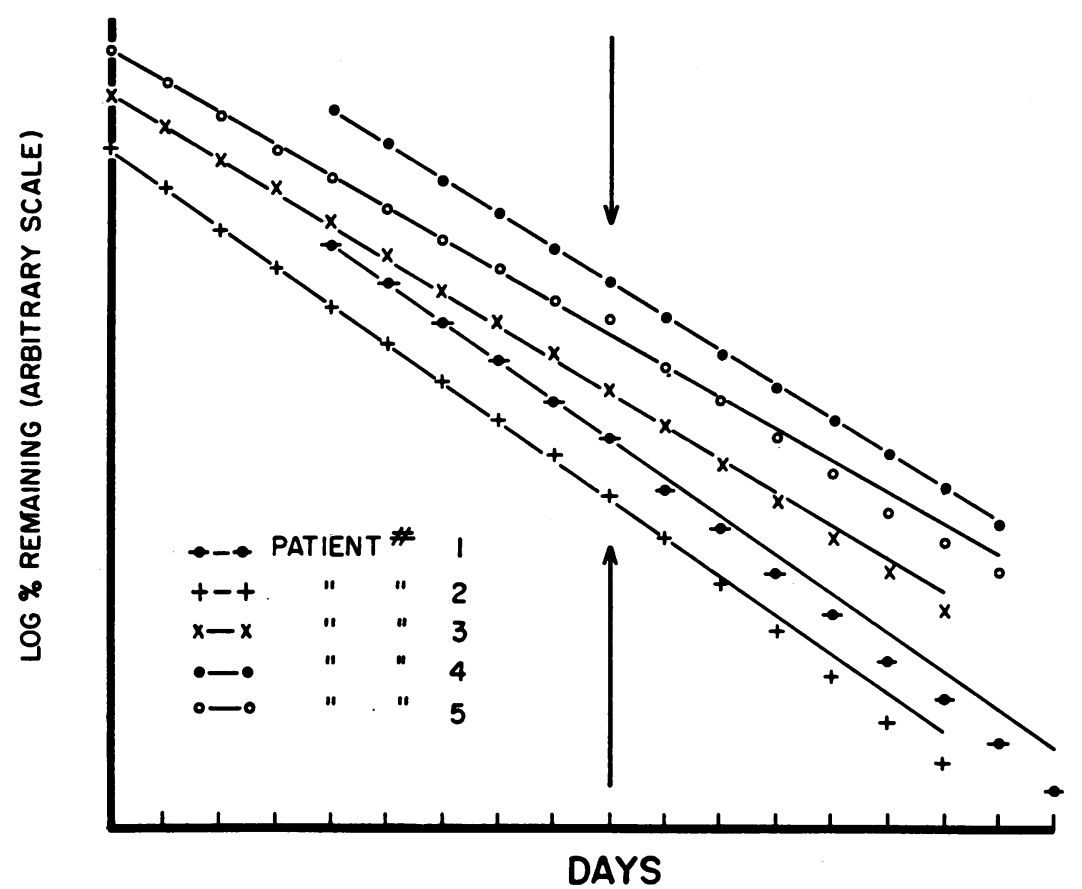

\section{LOW $(0.5 \mathrm{Gm}$. PROTEIN/Kg.) $\longrightarrow \longleftarrow H I G H(3.0 \mathrm{Gm}$. PROTEIN/Kg.)}

Fig. 3. Effect of InCReasing the Intake of Protein on the Rate of Degradation of Radioalbumin

The lines represent the least square fit line of the period of low protein administration extrapolated into the period of high protein administration. In all except No. 4 the points fall beneath the line indicating increased catabolism of albumin.

is accelerated by a sudden surfeit of protein in the diet. The maximum change was seen in Subject 1 in whom the half-life of the per cent remaining curve changed from 11.5 to 9.5 days. This represents an increased breakdown of approximately 1.2 grams of albumin per day. The albumin pool was 350 grams and this increase was 17 per cent in the per cent change per day. In addition to using the increased amounts of dietary protein for energy metabolism and protein stores (note the positive nitrogen balance), the body seems to increase the replacement rate of existing protein molecules; the lack of response in Subject 4 (Figures 3 and 4 ) is interesting, for this man had no functioning adrenal tissue and was maintained entirely on exogenous compound F (50 mg. per day). Administration of excess adrenal cortical hormones may produce increased protein catabolism (16, 17). The catabolic effect of sudden increases in the protein in the diet may therefore be mediated through the adrenal cortical hormones. It is possible that the prolonged survival of plasma proteins tagged with $\mathrm{S}^{35}$ observed by Armstrong and associates $(18,19)$. in uremia was due to relative protein starvation, if this were prescribed as part of treatment of the disease.

The diets used in this study were isocaloric and therefore increase in the protein content was accompanied by decrease in the fat and carbohydrate content. The possible effect of the concomitant changes in fat and carbohydrate intake on HISA catabolism was not investigated.

Influence of 1 -triiodothyroinine-Experimental and results. The effect of the acute administration of large doses of L-triiodothyronine on HISA catabolism was studied in four subjects (Table I, Subjects 3 to 6 ). A representative study is illustrated in Figure 5. The subject was observed for 14 days after the administration of HISA while the plasma and the per cent remaining radioactivity curves became stable. Five hundred micrograms (0.5 mg.) of L-triiodothyronine was then administered every 12 hours for 7 days 10 (Days 15 through 21), and measurement of the urine and plasma radioactivity was continued during, and for two weeks after, the triiodothyronine administration. A composite chart of the per cent remaining curves from all four subjects is presented in Figure 6. In all four curves there is a significant increase in the slope of the curve which corresponds in time to the period of negative nitrogen balance. Table II presents data derived from the experiments in each subject. The cumulative negative nitrogen balance during

10 In one experiment, Subject 4, triiodothyronine administration lasted only four days. 


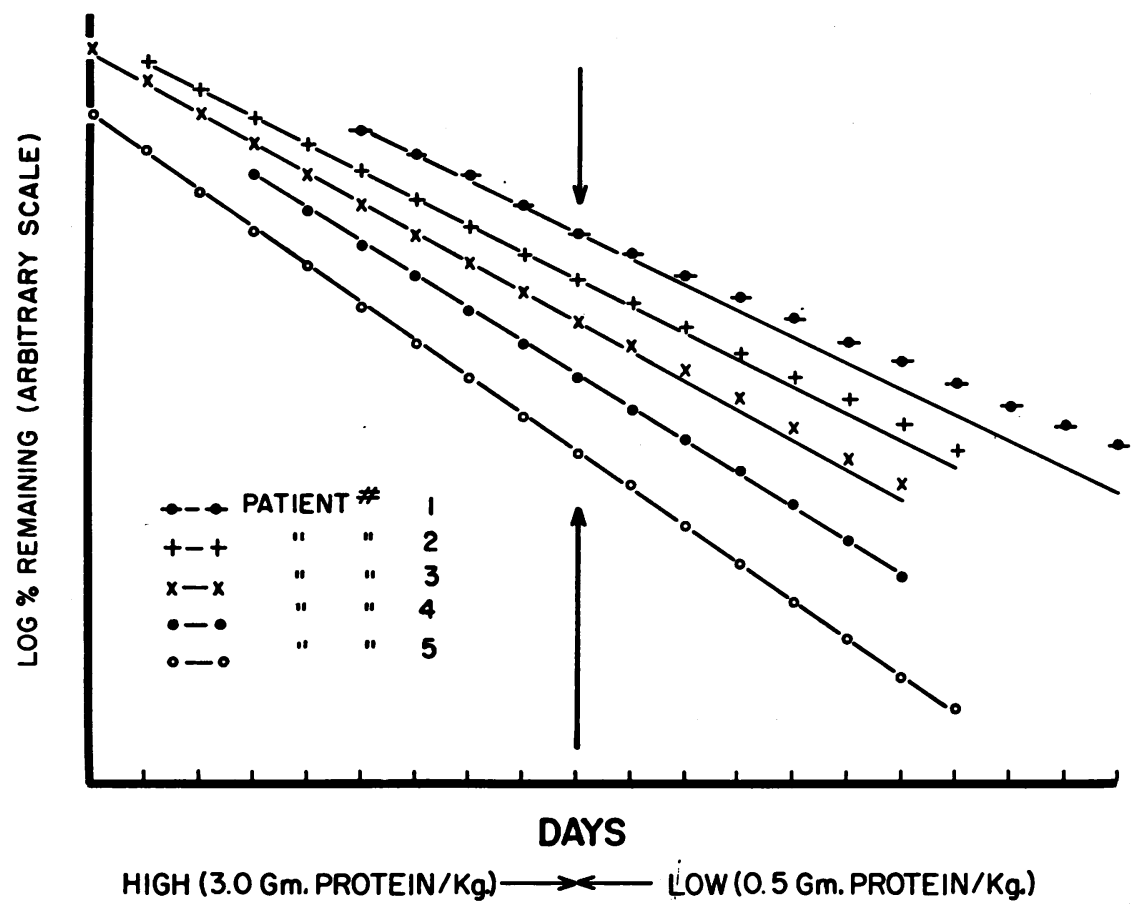

Fig. 4. Effect of Decreasing the Intake of Protein on the Rate of DEgradation OF Radioalbumin

The lines represent the best fitted line of the period of high protein administration extrapolated into the period of low protein administration. In all except Patients 4 and 5 the points fall above the line. The meaning of this change is uncertain.

the period of triiodothyronine administration, the size of the albumin pool and the percentage breakdown of the serum albumin per day, before and during triiodothyronine administration, are noted. The cumulative negative nitrogen balance was calculated from a baseline established during the control period and arbitrarily set as zero. This "negative" balance thus represents increased whole body nitrogen catabolism. Subjects 3 and 5 were on a diet containing adequate calories (approximately 35 cal. per $\mathrm{Kg}$.), whereas Subjects 4 and 6 were on deficient caloric intake; the latter pair showed a much greater increase in albumin catabolism during the period of triiodothyronine administration than the subjects on adequate calories. In the two on deficient diets, the increased catabolism of serum albumin was equivalent to 69 and 112 per cent of the cumulative negative nitrogen balance. In the two subjects on normal caloric intake, the increased catabolism of serum albumin was equivalent to 10 and 21 per cent of the negative nitrogen balance (see Table II). The average ratio of albumin nitrogen to total body nitrogen was 2.2 per cent (Column 6, Table II). In these studies no fall in the serum albumin was observed; therefore, it is likely that albumin anabolism increased and unlikely that the increased

TABLE II

Effect of triiodothyronine $(T-3)$ on albumin catabolism and nitrogen metabolism

\begin{tabular}{|c|c|c|c|c|c|c|c|c|c|c|}
\hline \multirow[b]{4}{*}{ Subject } & \multirow{4}{*}{$\begin{array}{c}\text { T-3 } \\
\text { duration }\end{array}$} & \multirow{4}{*}{$\begin{array}{c}(2) \\
\text { Cumu- } \\
\text { lative } \\
\text { negative } \\
\text { N } \\
\text { balance }\end{array}$} & \multirow{4}{*}{$\begin{array}{l}\text { (3) } \\
\text { Esti- } \\
\text { mated } \\
\text { total } \\
\text { body } N \\
\text { (Ref. 20) }\end{array}$} & (4) & (5) & \multirow{4}{*}{$\begin{array}{c}(6) \\
\frac{\text { Alb. N }}{\text { Total N }} \\
\frac{(5)}{(3)} \times 100\end{array}$} & (7) & (8) & \multirow{4}{*}{$\begin{array}{c}(9) \\
N \text { due to } \\
\text { increased } \\
\text { alb. breakdown } \\
\frac{(8)-(7) \times(1) \times(5)}{100}\end{array}$} & \multirow{4}{*}{$\begin{array}{c}(10) \\
\frac{(9)}{(2)} \times 100\end{array}$} \\
\hline & & & & \multirow{2}{*}{\multicolumn{2}{|c|}{ Albumin pool }} & & \multicolumn{2}{|c|}{$\begin{array}{l}\% \text { Breakdown } \\
\text { alb./day }\end{array}$} & & \\
\hline & & & & & & & \multirow{2}{*}{$\begin{array}{c}\text { Before } \\
\text { T-3 }\end{array}$} & \multirow{2}{*}{$\underset{T-3}{\text { During }}$} & & \\
\hline & & & & Alb. & $\mathbf{N}$ & & & & & \\
\hline no. & days & Gm. & $K g$. & $\mathrm{Gm}$ & $G m$ & $\%$ & & & Gm./day & $\%$ \\
\hline 3 & 7 & 17.3 & 1.31 & 224 & 35.9 & 2.7 & 3.77 & 4.5 & 1.8 & 10 \\
\hline 4 & 4 & 13.3 & 1.95 & 255 & 40.8 & 2.1 & 7.30 & 12.2 & 8.0 & 60 \\
\hline 5 & 7 & 31.3 & 2.42 & 302 & 48.3 & 2.0 & 6.35 & 8.3 & 6.6 & 21 \\
\hline 6 & 7 & 21.7 & 2.71 & 367 & 58.7 & 2.2 & 8.16 & 14.1 & 24.3 & 112 \\
\hline
\end{tabular}




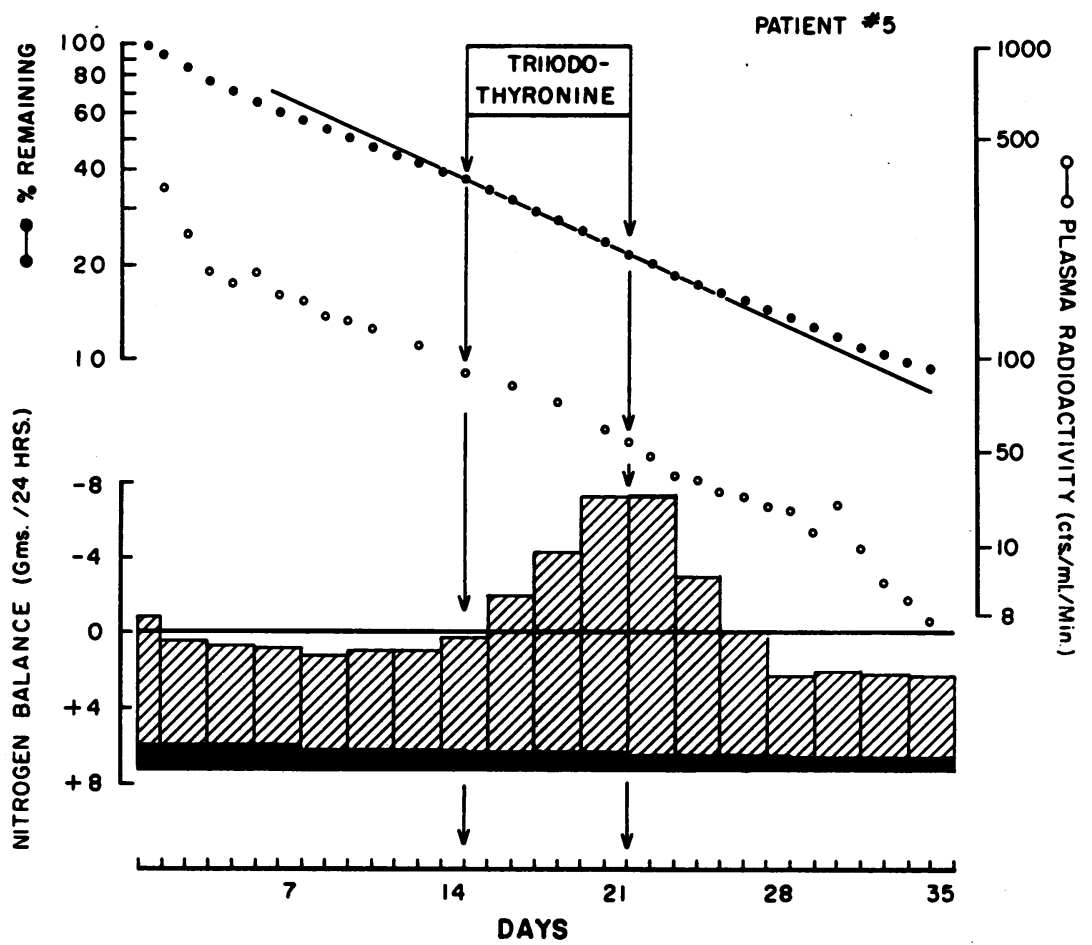

Fig. 5. Effect of Triodothyronine on Albumin Turnover

The line in the per cent remaining curve is the best fitted line to the points during triiodothyronine administration. Notice that the points in the precontrol period fall below this line and the points in the postcontrol period fall above it. In both, the rate of catabolism is slower than during triiodothyronine administration. The triiodothyronine effect persists longer than its time of administration, as indicated by the prolonged negative $\mathrm{N}$ balance. The plasma values have been divided by 1,000 .

albumin catabolism actually accounts for much of the negative nitrogen balance.

Discussion. Schwartz (21) reported that the half-life of HISA was increased in myxedema and that restoration of the euthyroid state was associated with a return of the biological half-life toward normal. These findings were confirmed by Lewallen, Rall, Berman and Hamel (22). Dixon, Maurer and Deichmiller (23) reported a

TABLE III

Comparison of triiodothyronine $(T-3)$ data

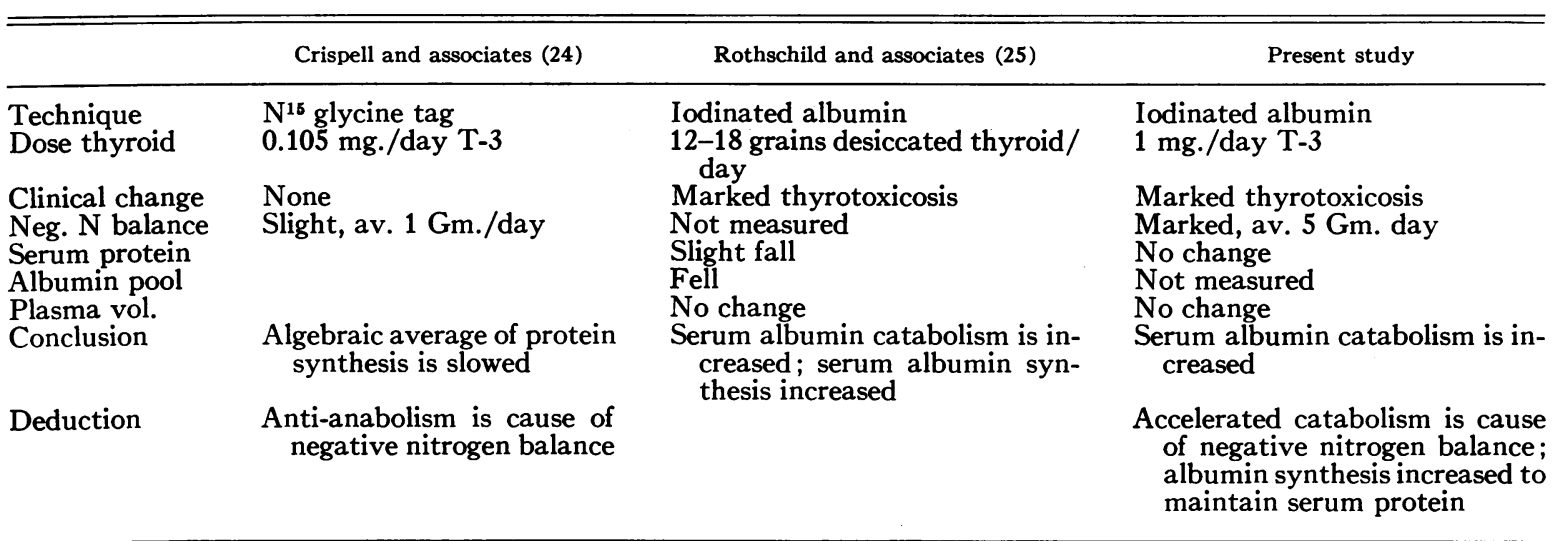




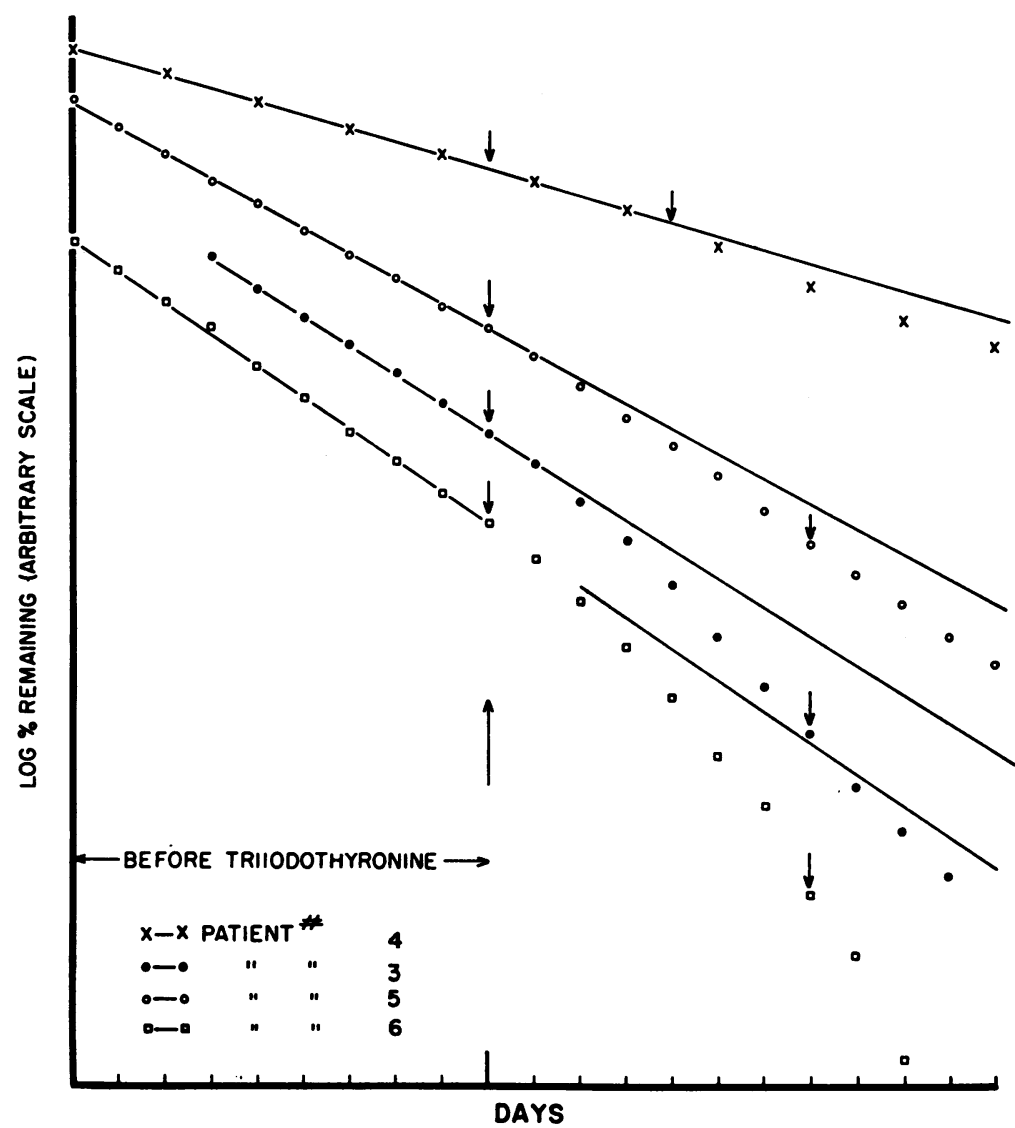

Fig. 6. Effect of Triodothyronine on Albumin Turnover

The arrows delineate the duration of triiodothyronine administration. The lines are the best fit during the pretriiodothyronine control period. Note the apparent persistence of triiodothyronine effect on the curves after cessation of its administration.

decreased half-life of labeled albumin in normal rabbits treated with thyroxine. Crispell, Parson and Hollifield (24) studied the incorporation of $\mathrm{N}^{15}$ labeled glycine into the body proteins in patients with primary myxedema and found that soon after the administration of minimal doses of triiodothyronine the rate of protein synthesis decreased, but at higher doses the rate increased toward normal. In a normal subject, small doses of triiodothyronine produced a definite decrease in the rate of protein synthesis.

Rothschild, Bauman, Yalow and Berson (25) have presented studies similar to the present ones in euthyroid subjects receiving 12 to 18 grains of desiccated thyroid daily. They found increased catabolism of serum albumin. The present study shows about twice the rate of catabolism during the control period as compared to Rothschild and co-workers' values, reflecting differences in the iodinated albumin employed. Rothschild and associates reported that the mean increased catabolism during thyroid administration was 30.3 per cent; the two subjects in the present study on normal diets showed values of 28 and 30 per cent. The two subjects on caloric deficient diets showed 60 and 75 per cent. Rothschild and associates found a decline in the serum albumin concentration and a fall in the total exchangeable albumin, but the latter fall was not as great as the increased catabolic rate would produce during the period of observation so that synthesis was increased. In our study a change in albumin concentration was not found and the plasma volume (T-1824) did not change. The similarities and the differences in the experimental studies of Crispell and co-workers (24), Rothschild and coworkers (25) and the present authors are presented in Table III, along with the conclusions and deductions that may be drawn.

From this it seems likely that thyroid hormone acts similarly in normal subjects receiving large doses and in myxedema subjects receiving replacement therapy. Both catabolism and anabolism of serum albumin are increased and negative nitrogen balance results, at least during the early administration. Anabolism of serum albumin is increased almost to the same degree that catabolism is increased. The lower dose of triiodothyronine 
employed by Crispell and associates (24) in a normal subject to demonstrate decreased anabolism was not used in the present study. The plasma values showed too great a scatter for statistically valid conclusions regarding albumin anabolism.

\section{GENERAL DISCUSSION}

HISA as it is commonly prepared gives variable plasma and per cent remaining curves, and this considerable biological variation has been emphasized (8). This variation is observed when the same lot is given to different individuals or when different lots are given at different times to the same individual. It has recently become possible to prepare iodinated proteins that have more reproducible half-lives, but these are not generally available (7). The HISA preparation used in this study has been compared with HISA produced by the more recent methods (26). The
HISA employed in these studies demonstrates this lack of reproducibility. Thus in Figures 3 and 4, the slopes of the curves on the lefthand half of the charts are not identical. Similarly, in Figure 2, the initial portion of the second per cent remaining curve has a much more shallow slope than the initial portion of the first curve, despite the fact that the patient is now on a higher protein intake. Thus, the comparison of moderate changes in the slope of HISA curves between individuals or between sequential studies in the same subject at different points in the course of diseases is not valid. It has been shown that a single HISA label will follow a predictable pattern (see discussion, Figure 1) for 35 days or more (Figure 7). By use of a single label for both the control and experimental study, comparisons become valid. This comparison holds even though HISA may not be

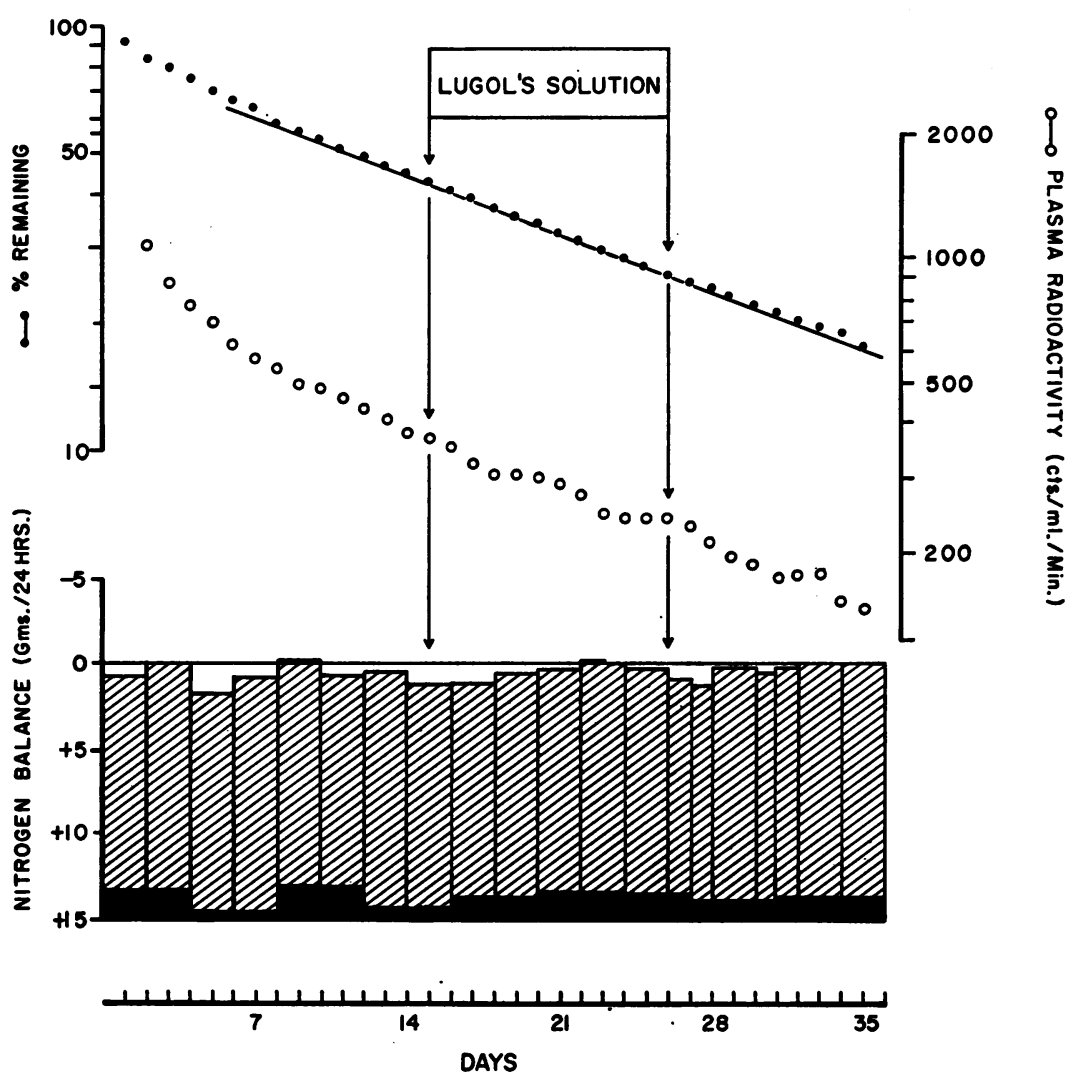

Fig. 7. Effect of Lugol's Solution on Albumin Turnover

The line in the per cent remaining curve is the best fitted line to the points during the administration of Lugol's solution. The points in the precontrol and postcontrol period do not differ significantly from this line. The nitrogen balance did not change during the administration of Lugol's solution. 
a perfect tracer for serum albumin. This technique was used by Lewallen and co-workers (22) prior to the first report of these studies (27).

The use of samples of plasma to establish the turnover curve has several deficiencies that are largely corrected by use of the cumulative urinary excretion or the per cent remaining curve. A plasma sample represents a variable daily aliquot of the total albumin pool subject to fluctuations of hydration. The cumulative urinary excretion, on the other hand, gives a sensitive daily measure of change in the entire albumin pool (28). The curve obtained from the plasma data is influenced by both anabolism and catabolism of the plasma proteins. The cumulative urinary excretion is a function only of catabolism.

An isotopic label that is significantly reincorporated into proteins cannot be used for such studies as these, for all of the findings could represent alteration in the rate of reincorporation. Sterling (1) has reviewed the overwhelming evidence that the radioactive label of iodinated proteins is not reincorporated into newly synthesized native proteins. Margen and Tarver (6) suggest that in vivo exchange of $\mathrm{I}^{127}$ with the radioactive $\mathrm{I}^{131}$ may occur and thus lead to a spuriously short life of iodinated proteins. To test such a possibility, Lugol's solution was administered to an athyroid subject after an HISA per cent remaining curve had been established. This administration did not alter the catabolic rate of HISA (Appendix and Figure 7). If such a mechanism as proposed by Margen and Tarver had been of measurable importance, increase in the apparent catabolism of HISA would have been expected.

In the present interpretation of the per cent remaining curve, it is assumed that the excretion of $I^{131}$ from the plasma into the urine remained constant. Thyroxine (29) increases renal blood flow. Could this change account for the experimental observations? The excretion of $\mathrm{I}^{131}$ is exceedingly rapid compared with the rate of breakdown of HISA (8) and, therefore, any increase in the renal clearance of $\mathrm{I}^{131}$ would manifest itself by an increased urinary excretion of $\mathrm{I}^{131}$ for one or two days, but this excretion would then return to the slower rate determined by the release of $\mathrm{I}^{131}$ from the catabolism of HISA. Such a possibility therefore seems unlikely.

\section{SUMMARY}

Human iodinated serum albumin was employed as a label of plasma albumin. A single injection of the label was used for both the control and experimental observations. Observations were made for periods up to 35 days. Very high protein intakes were found to accelerate the catabolism of serum albumin significantly over the values observed when the same subjects received isocaloric diets lower in protein. Triiodothyronine accelerated the catabolism of serum albumin simultaneously with the production of negative nitrogen balance.

\section{APPENDIX}

\section{Effect of Lugol's solution on HISA curves}

A male subject surgically rendered athyroid was studied some four months after surgery. The experimental design (Figure 7) was similar to that used for triiodothyronine except that he was not given Lugol's solution initially, for there was no need to block the thyroid. During the period from Day 15 to $26,0.2 \mathrm{ml}$. of Lugol's solution was administered orally three times daily. There was no significant change in the $\mathrm{N}$ balance, and the experimental points in both the precontrol and postcontrol period on the per cent remaining curve do not deviate significantly from the line defined during the administration of Lugol's solution. See text for discussion.

\section{ACKNOWLEDGMENT}

Captain Patty Shuman and her staff provided nursing care and continuous observations during these studies. The meticulous care of the dietary and laboratory staff at the Walter Reed Metabolic Ward was responsible for the precision of the data. Miss Marjorie Knowlton aided in all phases of the study. Dr. Glenn Bartsch provided assistance with the statistics. The cooperation of the seven volunteer subjects who willingly ingested liquid diets and permitted innumerable venipunctures is gratefully acknowledged.

\section{REFERENCES}

1. Sterling, $K$. The turnover rate of serum albumin in man as measured by $\mathrm{I}^{131}$-tagged albumin. $\mathrm{J}$. clin. Invest. 1951, 30, 1228.

2. Conference on "The Role of $\mathrm{I}^{131}$-Labeled Proteins in Biology and Medicine," S. P. Masouredis, Ed. Ann. N. Y. Acad. Sci. 1958, 70, p. 3.

3. Masouredis, S. P., and Beeckmans, M. L. Comparative behavior of $\mathrm{I}^{131}$ and $\mathrm{C}^{14}$ labelled albumin in plasma of man. Proc. Soc. exp. Biol. (N. Y.) 1955, 89, 398.

4. Volwiler, W., Goldsworthy, P. D., MacMartin, M. P., Wood, P. A., Mackay, I. R., and Fremont-Smith, 
K. Biosynthetic determination with radioactive sulfur of turn-over rates of various plasma proteins in normal and cirrhotic man. J. clin. Invest. $1955,34,1126$.

5. London, I. M. Studies on the rates of formation of serum proteins in man in Symposia on Nutrition. Vol. II. Plasma Proteins. Springfield, Ill., Charles C Thomas, 1950, pp. 72-82.

6. Margen, S., and Tarver, $H$. Comparative studies on the turnover of serum albumin in normal human subjects. J. clin. Invest. 1956, 35, 1161.

7. McFarlane, A. S. Labelling of plasma proteins with radioactive iodine. Biochem. J. 1956, 62, 135.

8. Berson, S. A., Yalow, R. S., Schreiber, S. S., and Post, J. Tracer experiments with $\mathrm{I}^{131}$ labeled human serum albumin: Distribution and degradation studies. J. clin. Invest. 1953, 32, 746.

9. Yalow, R. S., and Berson, S. A. Chemical and biological alterations induced by irradiation of $\mathrm{I}^{131}$ labeled human serum albumin. J. clin. Invest. 1957, 36, 44.

10. Forsyth, B. T., Shipman, M. E., and Plough, I. C. The relation of nitrogen retention to nitrogen intake in adults with post-traumatic malnutrition. J. clin. Invest. 1955, 34, 1653.

11. Knowlton, M., Seligson, D., Horner, W., and Iber, F. L. Analytical Procedures, Dept. of Metabolism, Walter Reed Army Institute of Research. Washington, D. C., U. S. Government Printing Office, 1955.

12. Snedecor, C. W. Statistical Methods Applied to Experiments in Agriculture and Biology, 5th ed. Ames, Iowa, Iowa State University Press, 1957.

13. Steinbock, H. L., and Tarver, H. Plasma protein. V. The effect of the protein content of the diet on turnover. J. biol. Chem. 1954, 209, 127.

14. Rutman, J., Rutman, R. J., and Tarver, H. Studies on protein synthesis in vitro. $\cdot V$. The effect of diet and fasting on the incorporation of methionine$\mathrm{S}^{35}$ into liver protein. J. biol. Chem. 1955, 212, 95.

15. Blahd, W. H., Fields, M., and Goldman, R. The turnover rate of serum albumin in the nephrotic syndrome as determined by $\mathrm{I}^{131}$-labeled albumin. $\mathrm{J}$. Lab. clin. Med. 1955, 46, 747.

16. Roberts, S. The influence of the adrenal cortex on the mobilization of tissue protein. J. biol. Chem. 1953, 200, 77.

17. Blythe, W. B., Iber, F. L., Werner, I., Rubini, M. E., Frick, P. G., and Meroney, W. H. The effect of hydrocortisone on simultaneously determined albumin turnover and nitrogen balance. Clin. Res. Proc. 1957, 5, 190.

18. Armstrong, S. H., Jr., McLeod, K., Wolter, J., and Kukral, J. The persistence in the blood of the radioactive label of albumin, gamma globulins, globulins of intermediate mobility studied with $\mathrm{S}^{25}$ and paper electrophoresis: Methods and preliminary results. J. Lab. clin. Med. 1954, 43, 918.

19. Armstrong, S. H., Jr., Bronsky, D., and Hershman, $\mathrm{J}$. The persistence in the blood of the radioactive label of albumin, gamma globulins, and globulins of intermediate mobility. III. Comparison of dieaway plots following oral and intravenous administration of the $\mathrm{S}^{35}$ label to the same subjects. J. Lab. clin. Med. 1955, 46, 857.

20. Edelman, I. S., Haley, H. B., Schloerb, P. R., Sheldon, D. B., Friis-Hansen, B. J., Stoll, G., and Moore, F. D. Further observations on total body water. I. Normal values throughout the life span. Surg. Gynec. Obstet. 1952, 95, 1.

21. Schwartz, E. The effect of thyroid hormone upon the degradation rate and miscible pool of radioiodinated human serum albumin in myxedema. J. Lab. clin. Med. 1955, 45, 340.

22. Lewallen, C. G., Rall, J. E., Berman, M., and Hamel, $H$. The effects of thyroid hormone on the distribution kinetics and degradation of iodo-albumin (abstract). J. clin. Invest. 1955, 34, 949.

23. Dixon, F. J., Maurer, P. H., and Deichmiller, M. P. Half-lives of homologous serum albumins in several species. Proc. Soc. exp. Biol. (N. Y.) 1953, 83, 287.

24. Crispell, K. R., Parson, W., and Hollifield, G. A study of the rate of protein synthesis before and during the administration of L-triiodothyronine to patients with myxedema and healthy volunteers using N-15 glycine. J. clin. Invest. 1956, 35, 164.

25. Rothschild, M. A., Bauman, A., Yalow, R. S., and Berson, S. A. The effect of large doses of desiccated thyroid on the distribution and metabolism of albumin- $\mathrm{I}^{131}$ in euthyroid subjects. J. clin. Invest. 1957, 36, 422.

26. Steinfeld, J. L., Paton, R. R., Flick, A. L., Milch, R. A., Beach, F. E., and Tabern, D. L. Distribution and degradation of human serum albumin labeled with $\mathrm{I}^{\mathbf{1 3 1}}$ by different techniques. Ann. N. Y. Acad. Sci. 1957, 70, 109.

27. Fremont-Smith, K., and Iber, F. L. The application of I-131 labeled albumin to the study of acute changes in protein metabolism in man (abstract). J. clin. Invest. 1956, 35, 705.

28. McFarlane, A. S. The behavior of $\mathrm{I}^{131}$-labeled plasma proteins in viz'o. Ann. N. Y. Acad. Sci. 1957, 70, 19.

29. Eiler, J. J., Althausen, T. L., and Stockholm, M. The effect of thyroxin on the maximum rate of transfer of glucose and diodrast by the renal tubules. Amer. J. Physiol. 1944, 140, 699. 